\title{
HIV testing and counselling in Estonian prisons, 2012 to 2013: aims, processes and impacts
}

K Kivimets (kristel.kivimets@just.ee) ${ }^{1}$, A Uusküla²

1. The Estonian Ministry of Justice, Prison Department, Rehabilitation Division, Jõhvi, Estonia

2. Department of Public Health, University of Tartu, Tartu, Estonia

Kivimets K, Uusküla A. HIV testing and counselling in Estonian prisons, 2012 to 2013: aims, processes and impacts. Euro Surveill. 2014;19(47):pii=20970. Available online: http://www.eurosurveillance.org/ViewArticle.aspx?Articleld=20970

We present data from an observational cohort study on human immunodeficiency virus (HIV) prevention and control measures in prisons in Estonia to assess the potential for HIV transmission in this setting. HIV testing and retesting data from the Estonian prison health department were used to estimate HIV prevalence and incidence in prison. Since 2002, voluntary HIV counselling and testing has routinely been offered to all prisoners and has been part of the new prisoners health check. At the end of 2012, there were 3,289 prisoners in Estonia, including 170 women: $28.5 \%$ were drug users and $15.6 \%$ were infected with HIV. Of the HIV-positive inmates, $8.3 \%$ were newly diagnosed on prison entry. In 2012, 4,387 HIV tests (including retests) were performed in Estonian prisons. Among 1,756 initially HIV-negative prisoners who were in prison for more than one year and therefore tested for HIV twice within 12 months (at entry and annual testing), one new HIV infection was detected, an incidence of 0.067 per 100 person-years ( $95 \%$ confidence interval (CI): 0.025-5.572). This analysis indicates low risk of HIV transmission in Estonian prisons. Implementation of HIV management interventions could impact positively on the health of prisoners and the communities to which they return.

\section{Introduction}

In most countries, the rates of human immunodeficiency virus (HIV) infection, tuberculosis (TB) and hepatitis $B$ and $C$ among prisoners are higher than those in the general population [1] owing to risk behaviour before and during incarceration. These risks include injection drug use [2,3], exchange of sex for money or drugs [4], multiple sex partners [5], and low socioeconomic status (homeless people). [6-8] Many people who inject drugs (PWID) engage in low-level criminal activity to support their drug use and many experience incarceration at least once in their lifetime [9]. Research has shown that HIV-infected people are frequently incarcerated during the course of their disease, with an estimated $17 \%$ of people living with HIV/AIDS in the United States (US) and incarcerated at some point in a given year [10]. In addition, female prisoners who have been involved with sex work, which is frequently associated with injection drug use and contact with HIV-infected sexual partners, are at additional risk of HIV being infected when entering prison. [11] The high prevalence of HIV infection and drug dependence among prisoners, combined with the sharing of injecting drug equipment, make prisons a high-risk environment for the transmission of HIV. Therefore, the World Health Organization (WHO) has recommended that HIV testing in prison settings should be prioritised [12].

A review by Dolan et al. suggests that prisons are a particular focus of the HIV epidemic in several countries in Europe, and that HIV infection rates are substantially higher among prisoners than among the general population in some countries in eastern Europe, e.g. above $10 \%$ nationally in Estonia, Romania, and Slovakia, and in a single prison or region in Lithuania and Ukraine [13]. Less is known about the implementation and effectiveness of HIV prevention and harm reduction programmes introduced in prisons in these countries.

This article assesses the prevalence of HIV infection among prisoners, and describes prison policies and practices on voluntary HIV testing and counselling (VCT) and retesting in Estonian prisons between January 2012 and March 2013.

\section{Situation in Estonia}

Estonia is a small country in north-eastern Europe with a population of ca 1.3 million [14]. In 2009, the estimated HIV prevalence among 15-49 years-olds in Estonia was $1.2 \%$ compared with $1.0 \%$ in Russia and $1.1 \%$ in Ukraine. In 2011, Estonia had the third highest rates of HIV diagnosis in Europe (27.3/100,000), after Russia (44.1/100,000 in 2010) and Ukraine $(38.0 / 100,000)$ [15]. Estonia has one of the highest prevalences of PWID among people aged 15-64 years (1.5\% in 2007 ) coupled with a $40-90 \%$ HIV prevalence among PWID $[16,17]$.

There are four prisons in Estonia: Tartu, Tallinn, Viru, and Harku and Murru. Data from the Estonian Ministry 
of Justice show that the prison population was ca 3,300 in January 2013 [18], translating into an imprisonment rate of 246 per 100,000 population. According to the Health Services Organisation Act, healthcare in prisons is part of the national healthcare system [19]. Prisoners' treatment costs are covered through the Ministry of Justice from the state budget [20].

HIV/AIDS prevention in prisons is based on the national HIV/AIDS Strategy 2006-2015. The main objective is to block HIV transmission inside prison. Antiretroviral therapy (ART) is available in all prisons and is administered according to the national guidelines, which require that $A R T$ should be initiated at a $C_{4} D_{4}$ cell count $<350$ cells $/ \mathrm{mm}^{3}$. Condoms are distributed free of charge in long-term visiting rooms. Drug prevention in the prison system was commenced in 1998. Until 2003 the focus was primarily on reducing the supply by inspection, but recently more attention has been paid to reducing the demand by treatment and rehabilitation of drug addicts [21]. Two types of drug dependency treatment are offered in Estonian prisons. Abstinencebased treatment is the most common and is available in all prisons. The only form of opiate substitution is methadone maintenance treatment and coverage is increasing every year. No prisons in Estonia offer needle exchange programmes.

On entry, all detained persons undergo an initial health check and VCT is a component of every new prisoner health check [20]. VCT is carried out by medical personnel and performed with the informed consent of the prisoner. Retesting for those who were HIV-negative at previous/initial testing is offered once a year or more often if necessary, i.e. if a prisoner can identify a specific incident of HIV exposure. Exposure incidents are tattooing, fighting, self-harm with dirty razors, unprotected sexual intercourse or injecting.

All HIV tests are performed in regional HIV screening laboratories (in Jõhvi, Tartu and Tallinn) using fourthgeneration HIV screening tests (i.e. Vironostika HIV Uniform II Ag/Ab, BioMerieux method). Confirmatory HIV testing (for those testing positive in a screening test) is done at the national HIV/AIDS reference laboratory in Tallinn (using the INNO LIA HIV I/II Score Western blot algorithm) [22]. According to the Communicable Diseases Prevention and Control Act [23] new cases of HIV are reported to the Estonian Health Board, an institution responsible for infectious disease surveillance in Estonia.

\section{Methods}

This work was based on the analysis of administrative data. The term 'prisoner' is used for all those, including adults and juveniles, detained during the investigation of a crime, while awaiting trial, after conviction, before sentencing, and after sentencing.

\section{Data and data sources}

Prison health reports

Data on the occurrence of drug dependence among inmates were obtained from the quarterly health reports from prisons summarised in the Estonian Ministry of Justice Drug Monitoring Report 2012 [24] which compiles all prison data on drug use, treatment and other preventive activities for the period from 1 January to 31 December 2012. Defining drug addiction status was based on ICD 10 diagnosis codes F11-F16 and F18-F19 [25].

These data were used to describe the prison population in Estonia in 2012, including HIV prevalence and ART coverage among those with HIV.

\section{Prison goals database}

The prison goals database is an electronic database containing aggregated information about HIV infection, HIV testing and retesting. Since the introduction of mandatory reporting of HIV testing in 2011, the database has been updated monthly by all prison medical departments. Data on HIV testing between 1 January and 31 December 2012 was extracted from the prison goals database. These data were used to describe HIV testing and retesting conducted in prisons in 2012.

\section{Prison electronic patient database}

The prison electronic patient database is an information system containing information from the electronic health records designed for prison healthcare. Individualised HIV testing and retesting results for the period from 1 January to 31 March 2013 were collected from the electronic prison patient database. Analysis was limited to prisoners who had been in prison for more than one year and had previously had a negative HIV test, i.e. those who were eligible for retesting. This information was used to explore the occurrence of newly acquired HIV infections (HIV incidence) among the prison population.

The data sources used for this study cover all the prisons in Estonia. Data on HIV/hepatitis C virus (HCV) testing and results, history of injection drug use, and condom use during conjugal visits (from the case management interview held following HIV diagnosis) on inmate newly infected in prison were also collected from the prison electronic patient database.

\section{Statistical analysis}

Descriptive statistics (proportions with 95\% confidence intervals (Cls)) were calculated using Microsoft Excel 2010. HIV incidence and $95 \%$ Cls were calculated using Poisson distribution.

The study complied with local data protection regulations. Data characteristics of the prison population, HIV testing and retesting in the year 2012 contained only non-identifiable (aggregated) data. The analysis of HIV testing and retesting results for the period 1 January 
Selected characteristics of prisoners in Estonia, 1 January-31 December 2012 (n=3,289)

\begin{tabular}{|c|c|c|c|c|c|}
\hline & Viru & Tartu & Tallinn & Harku /Murru & All \\
\hline Number of prisoners on 31 December 2012 & 950 & 920 & 1,157 & 262 & 3,289 \\
\hline Number of female prisoners & $9(0.9 \%)$ & $5(0.5 \%)$ & $46(4.0 \%)$ & $110(42.0)$ & $170(5.2)$ \\
\hline HIV-infected prisoners (n, \% of all) & $162(17.1 \%)$ & $78(8.5 \%)$ & $236(20.4 \%)$ & $43(16.4 \%)$ & $519(15.8 \%)$ \\
\hline Number of female HIV-infected prisoners & $3(33.3 \%)$ & $1(20.0 \%)$ & $19(41.3 \%)$ & $42(38.2 \%)$ & $65(38.2 \%)$ \\
\hline Prisoners on ART (n, \% of those infected) & $86(53.1 \%)$ & $57(73 \%)$ & $112(47.5 \%)$ & $26(60.4 \%)$ & $281(54.1 \%)$ \\
\hline
\end{tabular}

ART: antiretroviral therapy; HIV: human immunodeficiency virus.

to 31 March 2013 was based on identifiable individual human data, analysed by authorised personnel (author KK), and considered eligible for exemption by the ethics review board as the research was conducted by the head of a governmental agency (author KK is the Prison Department medical adviser) authorised to evaluate public programmes.

\section{Results}

The prison population in Estonia consisted of 3,289 people at the end of 2012. Of these, $5 \%$ were women, $32 \%$ were $30-39$ years-old, $1.2 \%$ were juveniles (under 18 years) and $1 \%$ were over 60 years-old [21].

At the end of $2012,15.6 \%$ of the 3,289 prisoners were infected with HIV (Table 1). The HIV prevalence was $38.2 \%$ among female and $14.5 \%$ among male prisoners in Estonian prisons. One third (28.5\%; $n=906)$ of the total prison population were diagnosed with drug addiction (diagnosis codes F11-16, F18-19) [25]: $50 \%$ of them were opiate users, $25 \%$ users of multiple drugs, $19 \%$ stimulant users, $4 \%$ cannabis users and $2 \%$ other (solvent).

A total of 4,387 HIV tests (including retests) were performed across Estonian prisons in 2012 (Table 2). Of those, 2,425 were tests of people when entering prison, a testing uptake rate of $97.3 \%$. Of the tests on admission, $1.8 \%(43 / 2,425$ resulted in a new HIV diagnosis. These 43 individuals diagnosed on prison entry correspond to $8.3 \%$ of the total of 519 HIV-positive inmates in 2012. In addition, 23 prisoners self-reported being
HIV-negative (or not sure of their HIV status) but were found to have had a previous HIV-positive test result recorded at the national HIV/AIDS reference laboratory. Two prisoners who self-reported being HIV-positive, had negative results when tested.

To estimate the HIV incidence in prison, data on HIV retesting conducted from 1 January 2013 to 31 March 2013 were used. The following analysis is limited to the 1,756 prisoners who had been in prison more than one year and who therefore had an opportunity for HIV retesting during the indicated period (the total prison population in Estonia (including persons under pretrial) was 3,294 as of 31 March 2013 [9].

On admission to prison, 220 prisoners (12.5\% of the 1,756; $95 \% \mathrm{Cl}: 11.5-13.6 \%)$ were already infected with HIV (Table 3). Of those who were HIV-negative at prison entry: $97 \%(1,489 / 1,536 ; 95 \% \mathrm{Cl}: 96.4-97.6 \%)$ were retested and found to be negative at the retest a year later. One prisoner was HIV-positive at the retest (translating into an HIV incidence of 0.067 per 100 person years; $95 \% \mathrm{Cl}: 0.025-5.572)$, while $3 \%(46 / 1,536$; $95 \% \mathrm{Cl}: 2.4-3.6 \%)$ did not agree to repeat testing.

Data from prison health medical records (previous HIV/ HCV testing and results, history of injection drug use and case management interview held following HIV diagnosis) on the newly infected inmate indicated that this prisoner may have become infected during conjugal visits from an HIV-positive partner. The inmate has been in prison for more than five years and their

\section{TABLE 2}

HIV testing and retesting in Estonian prisons, 1 January-31 December $2012(n=4,387)$

\begin{tabular}{|c|c|c|c|c|c|}
\hline & Viru & Tartu & Tallinn & Harku /Murru & All \\
\hline Total number of HIV tests done & 992 & 1,172 & 1,987 & 236 & 4,387 \\
\hline Number of retests done & 596 & 693 & 437 & 236 & 1,962 \\
\hline Number of those tested on admission to prison & 396 & 479 & 1,550 & 0 & 2,425 \\
\hline $\begin{array}{l}\text { Number of previously undiagnosed infections among those } \\
\text { tested on admission to prison (new infections detected) }\end{array}$ & 16 & 2 & 25 & 0 & 43 \\
\hline Number of HIV-positive prisoners & 162 & 78 & 236 & 43 & 519 \\
\hline
\end{tabular}

HIV: human immunodeficiency virus. 
HIV retesting in prisons, Estonia, 1 January-31 March $2013(n=1,756)$

\begin{tabular}{|l|c|c|c|c|c|}
\hline & Viru & Tartu & Tallinn & Harku /Murru \\
\hline In prison for more than one year & 569 & 581 & 412 & 194 & $\mathbf{1 , 7 5 6}$ \\
\hline Prisoners HIV-positive on entry to prison & 67 & 58 & 57 & 38 & $\mathbf{2 2 0}$ \\
\hline Prisoners HIV-negative at annual retest & 490 & 513 & 341 & 154 & $\mathbf{1 , 4 8 9}$ \\
\hline Prisoners HIV-positive at annual retest & 0 & 0 & 0 & 1 & $\mathbf{1}$ \\
\hline Prisoners refusing annual HIV retesting & 12 & 10 & 24 & 0 & 46 \\
\hline
\end{tabular}

previous HIV tests were negative. Moreover, the inmate also tested negative for HCV in 2012, an indication that the inmate probably did not inject drugs in prison as the HCV prevalence in PWID in Estonia has been documented very high (>90\%) [26]. There was no information in the medical records that would suggest a history of drug injection of the newly infected prisoner. During the year 2012, the inmate had several conjugal visits from their partner. The inmate indicated that they did not use condoms. Therefore, the infection was probably acquired sexually during a one of those visits.

\section{Discussion}

To our knowledge, this is the first article providing data on HIV in prisons from one of the European countries witnessing HIV epidemics related to injection drugs since the early 2000s. Our results document an HIV prevalence of $15.6 \%$ in prisons in Estonia. Based on the high prevalence of drug addiction among inmates and of drug-related crimes as a reason for imprisonment, we suggest that the high HIV prevalence observed among prisoners is probably related to injection drug use. Prisoners should not leave prison in a worse health condition than when they entered [27]. HIV transmission does occur in custody; however, many experts conclude from the available data that most HIVinfected inmates are probably infected before entering prison $[10,28]$. Nevertheless, collecting data on risk behaviours in prison is important because the absence of such data can be used to justify inaction [29].

In a systematic review on HIV prevalence in prisons in low and middle income countries in 2003-2004, information was presented for 75 countries. The HIV prevalence in prisons was more than $10 \%$ in 20 countries [13]. In 2001, Rotily et al. published results of a multicentre pilot study estimating the HIV prevalence in prisons in several European countries (including $4.1 \%$ in France, $3.1 \%$ in the Netherlands, $2.7 \%$ in Sweden, $1.2 \%$ in Italy, $0.9 \%$ in Germany, $0.7 \%$ in Scotland) [30]. However, it has recently been reported that the HIV prevalence was significantly higher among prisoners in those European countries that witnessed HIV epidemics driven mainly by injection drug use, e.g. 6.0\% in Portugal [31], 10\% among female prisoners in Portugal [32], $10.8 \%$ in Spain [33], and $19.8 \%$ in individuals released from prison within the last six months in Ukraine [34]. In most industrialised countries in western Europe and
North America, many prison entrants have a history of injecting drug use and thus already have a high HIV prevalence, higher than those in the respective general populations. Furthermore, the lack of or insufficient supply in most prisons of preventive measures such as clean needles and syringes or condoms, combined with stressful social conditions, create further opportunities for HIV transmission [35]. Several studies, including from Estonia, report that drug injecting occurs among prisoners [36]. However, few studies have documented the epidemic spread of HIV within prisons [37].

According to our data, the risk of HIV transmission was low in Estonian prisons in 2012 and 2013 (0.067 per 100 person-years). Low levels of transmission have previously been identified in prison, with an incidence of zero to four per 1,000 person-years [28]. A systematic review conducted on the basis of studies from the US reporting HIV incidence in the prison population provides a pooled HIV incidence of 0.08 per 100 person-years (95\% Cl: 0.0-0.24) among continuously incarcerated populations with a similar incidence estimation method to that used in our report [38].

Our results have several implications: they show (i) a need to provide comprehensive HIV prevention within prisons and (ii) a need to provide comprehensive HIV care to those infected, including substance abuse management.

In Estonia, 10-28\% of all new HIV infections during the period from 2000 to 2009 were diagnosed in prisons [39]. Our findings also indicate that, close to one 1oth (8.3\%) of HIV infected inmates were newly diagnosed on prison entry. We argue that there is a strong case for routine testing on entry into the Estonian prison system as newly diagnosed cases are identified and previously known cases can be referred for treatment. Early diagnosis of HIV infection provides an opportunity to improve patient health outcomes and will also improve public health. At the end of 2012 , 54\% of HIVseropositive prisoners in Estonia were receiving ART in prison [24], compared with ca $40 \%$ coverage of PWID in the community (data not shown).

Our analysis indicated a low risk of HIV transmission in Estonian prisons. However, it is important to retest those who tested negative but are at ongoing risk for 
acquiring HIV through high-risk behaviours and those who may be in the early stages of infection but have not yet developed a sufficient antibody level to be detected by serological testing, i.e. during the "window period' [40].

Our finding that the HIV prevalence in female inmates is substantially higher than in male inmates is in agreement with other published reports [41-45].

Our study has several limitations. It is possible that we have underestimated the risk of HIV transmission in the prison setting if the small proportion of inmates who refused retesting had a different risk profile (higher HIV incidence) from those who were retested. In the unlikely scenario of all of those declining retesting $(n=46)$ being infected with HIV within those 12 months, our HIV incidence estimate would have been higher (3.06 per 100 person-years). Furthermore, the HIV risk could be different among those in prison for periods shorter than 12 months. However, we believe that our results are representative of the prison population in Estonia given that the databases used cover all prisons in Estonia and are considered to be complete.

The state is responsible for adequately securing a prisoner's health by providing the required medical assistance [46]. Prisons continue to be effective targets for public health interventions [10]. HIV testing and linkage to care, both within prisons and in the community, comprise an important component of the 'seek and treat' strategy to prevent further HIV infections. Prison-based screening of infectious diseases, especially but not limited to HIV, in conjunction with treatment and linkage to community care is an important component of HIV prevention among high-risk communities. Significantly, for drug users at high risk of parenteral as well as sexual transmission, combined prevention strategies to reduce both transmission paths should not be overlooked.

\section{Conclusions}

Estonia is one of the European countries witnessing injection drug-related HIV epidemics since the early 2000s. Data on HIV prevalence of prison populations in the region of central and eastern Europe is very limited. The study was launched in 2013 and, at the time, no data on HIV transmission in Estonian prisons had been published. To our knowledge, this is one of few detailed descriptions and analyses of HIV testing designed to assess in-prison transmission of HIV infection in a country with high HIV prevalence in both the general population and the prison population. The aim of this article was to describe the HIV prevention and control measures used in Estonian prisons and to assess the potential for HIV transmission in this setting. Further we provide an estimate of HIV incidence inside prison (based on HIV testing and retesting results). This analysis indicates a low risk of HIV transmission in Estonian prisons. Outbreaks of HIV infection have occurred in prisons in several countries, demonstrating how rapidly HIV can spread in such settings. Retesting can ensure that if an outbreak occurs, control measures can effectively be implemented in the event of an outbreak [47]. HIV testing and counselling in prisons should not be limited to promoting prisoners' access to HIV testing and counselling, but must at the same time aim to mitigate the stigma and discrimination related to HIV [48].

Prison staff, in partnership with public health officials, should assess the adequacy of existing programmes and services for incarcerated populations and develop strategies to reduce HIV infection, both in prisons and in the community [49,50] Implementation of the HIV management interventions described in this article could have public health benefits including a positive impact on the health of prisoners and the communities to which they return. These findings provide a basis for prison and public health authorities to consider whether HIV testing, counselling and other preventive measures should be part of an HIV prevention package in prisons. The implementation of routine testing policies in prison offers opportunities to reach high risk individuals and engage them in HIV prevention and treatment.

\section{Conflict of interest}

KK is employed by the Estonian Ministry of Justice. The Estonian Ministry of Justice did not provide any financial support or place any restrictions on this research or publication.

\section{Authors' contributions}

All authors were involved in the design of the study. KK did the database research and was responsible for data management. All authors contributed to the writing of the paper and approved the final version.

\section{References}

1. United Nations Office on Drugs and Crime (UNODC). HIV in prisons. Situation and needs assessment toolkit. Vienna: UNOCD; 2011. Available from: http://www.unodc.org/ documents/hiv-aids/publications/HIV_in_prisons_situation_ and_needs_assessment_document.pd̄f

2. Mumola CJ, Karberg JC. Drug Use and Dependence, State and Federal Prisoners, 2004. Washington, DC: US Department of Justice; 2006.

3. Wilson DJ. Drug Use, Testing, Treatment in Jails. Washington, DC: US Department of Justice; 2000.

4. McClelland GM, Teplin LA, Abram KM, Jacobs N. HIV and AIDS risk behaviors among female jail detainees: implications for public health policy. Am J Public Health. 2002;92(5):818-25. Available from: http://dx.doi.org/10.2105/AJPH.92.5.818 PMID:11988453

5. Margolis AD, MacGowan RJ, Grinstead O, Sosman J, Kashif I, Flanigan TP, et al. Unprotected sex with multiple partners: implications for HIV prevention among young men with a history of incarceration. Sex Transm Dis. 2006;33(3):17580. Available from: http://dx.doi.org/10.1097/01. olq.0000187232.49111.48 PMID:16505732

6. Baussano I, Williams BG, Nunn P, Beggiato M, Fedeli U, Scano F. Tuberculosis incidence in prisons: a systematic review. PLoS Med. 2010;7(12):e1000381. Available from: http://dx.doi. org/10.1371/journal.pmed.1000381 PMID:21203587

7. Reyes H, Coninx R. Pitfalls of tuberculosis programmes in prisons. BMJ. 1997;315(7120):1447-50. Available from: http:// dx.doi.org/10.1136/bmj.315.7120.1447 PMID:9418098 
8. Stuckler D, Basu S, McKee M, King L. Mass incarceration can explain population increases in TB and multidrug-resistant TB in European and central Asian countries. Proc Natl Acad Sci USA. 2008;105(36):13280-5. Available from: http://dx.doi. org/10.1073/pnas.0801200105 PMID:18728189

9. Kinner SA, George J, Campbell G, Degenhardt L. Crime, drugs and distress: patterns of drug use and harm among criminally involved injecting drug users in Australia. Aust N Z J Public Health. 2009;33(3):223-7. Available from: http://dx.doi. org/10.1111/j.1753-6405.2009.00379.x PMID:19630840

10. Spaulding AC, Seals RM, Page MJ, Brzozowski AK, Rhodes W, Hammett TM. HIV/AIDS among inmates of and releases from US correctional facilities, 2006: Declining share of epidemic but persistent public health opportunity. PLOS ONE. 2009;4(11):e7558. Available from: http://dx.doi.org/10.1371/ journal.pone.0007558 PMID: 19907649

11. Kantor E. HIV Transmission and Prevention in Prisons. In: HIV InSite. San Francisco: UCSF Center for HIV Information; April 2006. Available from: http://hivinsite.ucsf.edu/ insite? page $=\mathrm{kb}-07-04-13$

12. World Health Organization (WHO), UNAIDS, UNICEF. Towards universal access: Scaling up priority HIV/AIDS interventions in the health sector. Progress report 2008. Geneva: WHO; 2008. Available from: http://www.who.int/hiv/pub/towards universal_access_report_2008.pdf?ua=1

13. Dolan K, Kite B, Black E, Aceijas C, Stimson GV. Reference Group on HIV/AIDS Prevention and Care among Injecting Drug Users in Developing and Transitional Countries. HIV in prison in low-income and middle-income countries. Lancet Infect Dis. 2007;7(1):32-41. Available from: http://dx.doi.org/10.1016/ S1473-3099(06)70685-5 PMID:17182342

14. Rahvaloendusel loendati 1294236 Eesti püsielanikku. [Census counted 1,294,236 permanent residents of Estonia]. Tallinn: Statistics Estonia. [Accessed 13 August 2013]. Estonian. Available from: http://www.stat.ee/63779? parent_id=32784

15. European Centre for Disease Prevention and Control (ECDC) and World Health Organization Regional Office for Europe. HIV/ AIDS Surveillance in Europe 2011. Stockholm: ECDC; 2012.; Available from http://www.ecdc.europa.eu/en/publications/ Publications/20121130-Annual-HIV-Surveillance-Report.pdf

16. Mathers BM, Degenhardt L, Phillips B, Wiessing L, Hickman M, Strathdee SA, et al. Global epidemiology of injecting drug use and HIV among people who inject drugs: a systematic review. Lancet. 2008;372(9651):1733-45.

17. Uusküla A, Des Jarlais DC, Kals M, Rüütel K, Abel-Ollo K, Talu $A$, et al. Expanded syringe exchange programs and reduced HIV infection among new injection drug users in Tallinn, Estonia. BMC Public Health. 2011;11(1):517. Available from: http://dx.doi.org/10.1186/1471-2458-11-517 PMID:21718469

18. Prison Service. Prisons Department of Ministry of Justice. Tallinn: Estonian Ministry of Justice. [Accessed: 15 February 2013]. Available from: http://www.vangla.ee/43630

19. Health Services Organisation Act. Riigi Teataja [State gazette]; 9 December 2013. Available from: https://www.riigiteataja.ee/ en/compare_original id $=512122013005$

20. Prison Service. Healthcare. Tallinn: Estonian Ministry of Justice. [Accessed 15 February 2013]. Available from: http:// www.vangla.ee/43649

21. Vanglateenistus. [Prison Service]. Vanglate ja kriminaalhoolduse aastaraamat. [Estonian Prison System and Probation Supervision Yearbook]. Tallinn, Ministry of Justice; 2008. Estonian. Available from: http://www.vangla.ee/orb.aw/ class $=$ file $/$ action $=$ preview $/ \mathrm{id}=36156 /$ Estonian + Prison + System +and+Probation+Supervision+Yearbook+2007.pdf

22. HIV-nakkuse testimise ja HIV-positiivsete isikute ravile suunamise tegevusjuhis. [Operating instructions for HIV testing and referral to treatment for HIV-positive persons]. Tallin: Estonian Ministry of Social Affairs. [Accessed: 13August 2013]. Estonian. Available from: http://www.terviseinfo.ee/ images/HIV_testimise_juhis.pdf

23. Communicable Diseases Prevention and Control Act. Riigi Teataja [State gazette]; 12 February 2003. Available from: https://www.riigiteataja.ee/en/eli/ee/511112014003/consoled

24. Vanglateenistus. [Prison Service]. Uimastiseire. [Drug Monitoring Report 2012]. Tallinn: Estonian Ministry of Justice; 2012. Estonian.

25. World Health Organization (WHO). International statistical classification of diseases and related health problems 1oth revision (ICD-10). Version for 2010. Geneva: WHO; 2010. Available from: http://www.who.int/classifications/icd10/ browse/2010/en

26. Uusküla A, Heimer R, Dehovitz J, Fischer K, McNutt L-A. Surveillance of HIV, hepatitis B virus, and hepatitis $C$ virus in an estonian injection drug-using population: sensitivity and specificity of testing syringes for public health surveillance.
J Infect Dis. 2006;193(3):455-7. Available from: http://dx.doi. org/10.1086/499436 PMID:16388495

27. World Health Organization Regional Office for Europe (WHO Europe). Health in prisons. A WHO guide to the essentials in prison health. Copenhagen: WHO Europe; 2007. Available from: http://www.euro.who.int/__data/assets/pdf_file/0009/99018/ E90174.pdf

28. Weinbaum CM, Sabin KM, Santibanez SS. Hepatitis B, hepatitis C, and HIV in correctional populations: a review of epidemiology and prevention. AIDS. 2005;19(Suppl 3):S41-6. Available from: http://dx.doi.org/10.1097/01. aids.0000192069.95819.aa PMID:16251827

29. Dolan K. Aids, drugs and risk behaviour on prison: state of the art. National Drug and Alcohol Research Centre, University of New South Wales, Sydney, Australia, 1997.

30. Rotily M, Weilandt C, Bird SM, Käll K, Van Haastrecht HJ, landolo $\mathrm{E}$, et al. Surveillance of HIV infection and related risk behaviour in European prisons. A multicentre pilot study. Eur Public Health. 2001;11(3):243-50. Available from: http://dx.doi. org/10.1093/eurpub/11.3.243 PMID:11582600

31. Marques NM, Margalho R, Melo MJ, Cunha JG, Meliço-Silvestre AA. Seroepidemiological survey of transmissible infectious diseases in a Portuguese prison establishment. Braz J Infect Dis. 2011;15(3):272-5. Available from: http://dx.doi. org/10.1016/S1413-8670(11)70188-X PMID:21670930

32. Barros H, Ramos E, Lucas R. A survey of HIV and HCV among female prison inmates in Portugal. Cent Eur J Public Health. 2008;16(3):116-20. Available from: http://www.ncbi.nlm.nih. gov/pubmed/18935775 PMID:18935775

33. Marco A, Saiz de la Hoya P, García-Guerrero J, Grupo PREVALHEP. [Multi-centre study of the prevalence of infection from HIV and associated factors in Spanish prisons]. Rev Esp Sanid Penit. 2012;14(1):19-27. Spanish. http://dx.doi. org/10.4321/S1575-06202012000100004 PMID:22437905

34. Azbel L, Wickersham JA, Grishaev Y, Dvoryak S, Altice FL. Burden of infectious diseases, substance use disorders, and mental illness among Ukrainian prisoners transitioning to the community. PLoS ONE. 2013;8(3):e59643. Available from: http://dx.doi.org/10.1371/journal.pone.0059643 PMID:23527238

35. Hellard ME, Aitken CK. HIV in prison: what are the risks and what can be done? Sex Health. 2004;1(2):107-13. Available from: http://dx.doi.org/10.1071/SH03018 PMID:16334992

36. Platt L, Bobrova N, Rhodes T, Uusküla A, Parry JV, Rüütel $\mathrm{K}$, et al. High HIV prevalence among injecting drug users in Estonia: implications for understanding the risk environment. AIDS. 2006;20(16):2120-3. Available from: http://dx.doi. org/10.1097/01.aids.0000247586.23696.20 PMID:17053361

37. Taylor A, Goldberg D, Emslie J, Wrench J, Gruer L, Cameron $S$, et al. Outbreak of HIV infection in a Scottish prison. BMJ. 1995;310(6975):289-92. Available from: http://dx.doi. org/10.1136/bmj.310.6975.289 http://www.ncbi.nlm.nih.gov/ pmc/articles/PMC2548692/?page=1 PMID:7866169

38. Gough E, Kempf MC, Graham L, Manzanero M, Hook EW, Bartolucci A, et al. HIV and hepatitis $B$ and $C$ incidence rates in US correctional populations and high risk groups: a systematic review and meta-analysis. BMC Public Health. 2010;10(1):777. Available from: http://dx.doi.org/10.1186/1471-2458-10-777 PMID:21176146

39. Infectious disease. HIV/AIDS. Tallin: Estonian Health Board. [Accessed 15 February 2013].

40. World Health Organization (WHO). UNAIDS, UNICEF. Delivering HIV test result and messages for re-testing and counselling in adults. Geneva: WHO; 2012. Available from: http://whqlibdoc. who.int/publications/2010/9789241599115_eng.pdf?ua=1

41. Weild AR, Gill ON, Bennett D, Livingstone SJ, Parry JV, Curran L. Prevalence of HIV, hepatitis B, and hepatitis C antibodies in prisoners in England and Wales: a national survey. Commun Dis Public Health. 2000;3(2):121-6. Available from: PMID:10902255

42. Health Protection Agency (HPA). Health protection in prisons. 2009-2010 report. London: HPA; 2011. Available from: http:// webarchive.nationalarchives.gov.uk/20140714084352/ http://www.hpa.org.uk/webc/HPAwebFile/ HPAweb_C/1296682990869

43. Magnani R, Riono P, Nurhayati E, Saputro E, Mustikawati $D$, Anartati A, et al. Sexual risk behaviours, HIV and other sexually transmitted infections among female sex workers in Indonesia. Sex Transm Infect. 2010;86(5):393-9. Available from: http://dx.doi.org/10.1136/sti.2009.038059 PMID:20522622

44. Vandepitte J, Bukenya J, Weiss HA, Nakubulwa S, Francis SC, Hughes P, et al. HIV and other sexually transmitted infections in a cohort of women involved in high-risk sexual behavior in Kampala, Uganda. Sex Transm Dis. 2011;38(4):316-23. Available from: PMID:23330152〈/jrn〉 
45. Pettifor A, MacPhail C, Corneli A, Sibeko J, Kamanga G,

Rosenberg $\mathrm{N}$, et al. Continued high risk sexual behavior

following diagnosis with acute HIV infection in South Africa

and Malawi: implications for prevention. AIDS Behav.

2011;15(6):1243-50. Available from: http://dx.doi.org/10.1007/

S10461-010-9839-0 PMID:20978833

46. Abbing HR. Prisoners right to healthcare, a European perspective. Eur J Health Law. 2013;20(1):5-19. Available from: http://dx.doi.org/10.1163/15718093-12341251 PMID:23544314

47. World Health Organization (WHO). UNAIDS, UNOCD.

Effectiveness of interventions to address HIV in prisons.

Geneva: WHO; 2007. Available from: http://www.who.int/hiv/ idu/OMS_E4Acomprehensive_WEB.pdf

48. United Nations Office on Drugs and Crime (UNOCD), UNAIDS,

World Health Organization (WHO). HIV testing and counselling

in prisons and other closed settings. New York: United Nations; 2009. Available from: http://www.unodc.org/documents/hivaids/Final_UNODC_WHO_UNAIDS_technical_paper_2009_TC prison_ebook.pdf

49. Centers for Disease Control and Prevention (CDC). HIV transmission among male inmates in a state prison system - Georgia, 1992-2005. MMWR Morb Mortal Wkly Rep. 2006;55(15):421-6.

50. Jafa K, McElroy P, Fitzpatrick L, Borkowf CB, Macgowan R, Margolis A, et al. HIV transmission in a state prison system, 1988-2005. PLoS ONE. 2009;4(5):e5416. Available from: http:// dx.doi.org/10.1371/journal.pone.0005416 PMID:19412547 